\title{
Deep water flow speed and surface ocean changes in the subtropical North Atlantic during the last deglaciation
}

Hall, I. R ${ }^{1}$. Evans, H. K. and D.J.R. Thornalley

School of Earth, Ocean and Planetary Science, Main Building, Park Place, Cardiff University, Cardiff CF10 3YE, UK

${ }^{1}$ To whom correspondence should be addressed

\begin{abstract}
Climate fluctuations during the last deglaciation have been linked to changes in North Atlantic Meridional Overturning Circulation (MOC) through its modulation of northward marine heat transport. Consequently, much research into the causes of rapid climate change has focused on the northern North Atlantic as a key component of global ocean circulation. The production of cold, deep waters in the Southern Ocean is an important factor in the Earth's heat budget, but the involvement of deep Southern Sourced Water (SSW) in deglacial climate change has yet to be fully established. Here we use terrigenous silt grain size data from two ocean sediment cores retrieved from the western subtropical North Atlantic to reconstruct past changes in the speed of deepwater flow. The first core site is located under the influence of Lower North Atlantic Deep Water (LNADW), and is representative of changes in the MOC. The second core site is close to the modern boundary between LNADW/SSW and is therefore ideally positioned to detect changes in SSW delivery to the North Atlantic. We find evidence for a broad-scale difference in flow speed
\end{abstract}


changes at the two sites, with the presence of a vigorous, but poorly ventilated SSW mass at $\sim 4200 \mathrm{~m}$ water depth during the cold episodes of the last deglaciation when shallower (2975 m water depth) grain size and geochemical data suggest that Northern Sourced Water (NSW) was suppressed.

Keywords: Rapid Climate Change, deglaciation, Ocean Circulation, Deep Western

Keywords: Rapid Climate Change, deglaciation, Ocean Circulation, Deep Western Boundary Current 


\section{Introduction}

Records from Greenland ice cores have revealed that the last deglaciation was punctuated by several millennial-scale climate events (Alley et al., 1993; Blunier and Brook, 2001; Chappellaz et al., 1993). As the deep ocean is one of the largest reservoirs of heat and carbon in the climate system changes in the Meridional Overturning Circulation (MOC) are likely to have played a central role in controlling and responding to such rapid climatic variations (Broecker et al., 1985; Clark et al., 2002 and references therein). The MOC is characterized by the sinking of oxygenated and nutrient-depleted North Atlantic Deep Water (NADW), formed when northwardly advected surface waters release their heat in the Norwegian-Greenland (Mauritzen, 1996), and Labrador (Dickson and Brown, 1994) Seas. These waters are entrained by the southwards flowing Deep Western Boundary Current (DWBC) with an outflow of about 20 Sverdrups $\left(1 \mathrm{~Sv}=10^{6} \mathrm{~m}^{3} \mathrm{~s}^{-1}\right)($ Schmitz and McCartney, 1993), which is progressively undercut by nutrient enriched Southern Sourced Water (SSW) inflowing via the southwest Atlantic. In the modern western North Atlantic NADW is mainly confined above the 4,000 $\mathrm{m}$ isobaths (Stahr and Sanford, 1999), while a greater proportion of re-circulated SSW resides at depth (Hogg, 1983) (Figure 1). The behavior of NADW during the last glacial cycle has been investigated at many sites (e.g. Boyle and Keigwin, 1985; Marchitto et al., 1998b; Raymo et al., 2004), but the history of SSW in the North Atlantic remains relatively unstudied. Tracers from marine sediments have revealed that during the last glacial maximum (LGM) the boundary between Northern Sourced Water (NSW) and SSW shoaled to $2,000 \mathrm{~m}$ in the western North Atlantic (Curry and Oppo, 2005; Keigwin, 2004; Oppo and Lehman, 1993) and the transition from the LGM to the modern state was marked by a series of changes in the deep-ocean circulation (Boyle and Keigwin, 1987; Marchitto 
et al., 1998a; McManus et al., 2004). The paleohydrography of SSW has yet to be fully established with recent suggestions of a more saline SSW mass during the LGM compared with its modern equivalent (Adkins et al., 2002; Adkins and Schrag, 2003). The dynamics of this SSW also remain poorly understood with some evidence hinting at vigorous flow during cool periods (e.g. Masse et al., 1994).

The most prominent deglacial cooling event in the high latitude North Atlantic was the Younger Dryas (YD) cold event (or Greenland Stadial 1, 12.8-11.7 kyr BP, Lowe et al., 2008). Previous studies of the YD have suggested a freshwater induced slowdown of NADW production (Broecker, 1998; Broecker, 2006), resulting in a decrease in the northward heat transport and widespread cooling in the subpolar North Atlantic. Previous work have also shown increasing sea surface temperature (SST) trends during the YD in the Tobago Basin (Hüls and Zahn, 2000; Rühlemann et al., 1999), the Caribbean Sea (Schmidt et al., 2004), off the coast of Brazil (Weldeab et al., 2006), in the Gulf of Mexico (Flower et al., 2004) and the Blake Outer Ridge (Carlson et al., 2008). A similar asynchronous pattern between cooling SST at northern latitudes and the warming (sub)tropics is also observed at a range of locations during Heinrich Event 1 (H1; e.g. Carlson et al., 2008; Flower et al., 2004; Hüls and Zahn, 2000; Rühlemann et al., 1999; Schmidt et al., 2004; Weldeab et al., 2006). There is, however, considerable disagreement on the exact timing, magnitude and spatial pattern of SST variability which could have important implications on our understanding of climate change induced by variability in the MOC (e.g. Carlson et al., 2008).

Here we use terrigenous silt grain size data together with paired $\delta^{18} \mathrm{O}$ and $\mathrm{Mg} / \mathrm{Ca}$ measurements on the planktonic foraminifera Globigerinoides ruber (white) obtained from two high-accumulation rate sediment cores, recovered from the crest of 
the Blake Outer Ridge (BOR), in the western subtropical North Atlantic, to reconstruct surface ocean and near bottom flow speeds changes in relation to circumNorth Atlantic climate variability throughout the last deglacial period. Changes in surface and deepwater hydrography at the BOR are intricately associated with variability in high-latitude circum-North Atlantic climates and, in particular, the convective formation of deep waters, as it is the warm, salty surface water reservoir in the western subtropical Atlantic that provides the source of the warm surface waters that transport heat to the subpolar North Atlantic, through the North Atlantic Current, to compensate for the southward flow of NADW (Broecker, 1991). .

\section{Material and Methods}

Sediment core KNR140/2-39GGC $\left(31^{\circ} 66.8 \mathbb{N}\right.$, $75^{\circ} 41.5 \mathbf{N j} ; 2,975 \mathrm{~m}$ water depth, hereafter 39GGC) lies in modern lower (L)NADW, while KNR140/2-28GGC $\left(30^{\circ} 09.8 \mathrm{~N}\right.$, $73^{\circ} 83.6 \mathrm{Nj} ; 4,211 \mathrm{~m}$ water depth, hereafter $\left.28 \mathrm{GGC}\right)$ lies on the boundary between modern LNADW/SSW (Stahr and Sanford, 1999) and is ideally located to record changes in SSW delivery to the North Atlantic (Figure 1). These sediment cores provide high resolution paleoceanographic records spanning the last deglaciation (e.g. Keigwin, 2004; Keigwin and Schlegel, 2002) (Figure 2). Samples were collected every $2 \mathrm{~cm}$ throughout the 20-5 kyr BP interval with the exception of the YD which was sampled at $1 \mathrm{~cm}$ intervals.

To examine variability in the deep ocean flow intensity we employ the grain size distribution within the 10-63 $\mu \mathrm{m}$ terrigenous (biogenic carbonate and opal removed) sub-fraction, the ñsortable siltò mean grain size ( $\overline{\mathrm{SS}}$, (McCave and Hall, 2006), where fluctuations reflect relative changes in the intensity of the near-bottom current through selective deposition, with coarser mean values representing more vigorous near-bottom current speeds and vice versa. Measurements were undertaken 
using a Coulter Counter Multisizer III as outlined in Bianchi et al. (1999). The SS\% varies in the range of $5-10 \%$ enabling the determination of the $\overline{\mathrm{SS}}$ with an analytical error of 2-3\% (Bianchi et al., 1999). There is no evidence of sediment supply by down slope mass movement present in the cores and no ice rafted debris (IRD) was found in the $>150 \mu \mathrm{m}$ fraction. In order to highlight the magnitude of the variability in the $\overline{\mathrm{SS}}$ data (Figure 3) against the background signal and enable a comparison of the two records against a common baseline, the grain size values were normalised (Haskell et al., 1991) about a common mean set equal to zero. To achieve this it was assumed that each site exhibits full glacial to interglacial variability. Despite having a record starting from the late Holocene, core $28 \mathrm{GGC}$ is assumed to have values representative of the Holocene interval which does not seem unreasonable given that the few values between 10.5-8 kyr are consistent with each other. Normalised grain size data was further smoothed using a Gaussian filter with a 400 year window and bandwidth of 1200 years (Figure 4).

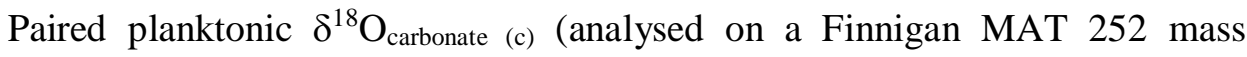
spectrometer coupled with an automated Kiel carbonate preparation device with a precision of 0.06 ă ) and $\mathrm{Mg} / \mathrm{Ca}$ (following methods of (Barker et al., 2005; Barker et al., 2003) measurements on the planktonic foraminifera Globigerinoides ruber (white) from the $150-250 \mu \mathrm{m}$ fraction of the same samples were carried out on core $39 \mathrm{GGC}$ to reconstruct sea surface temperatures (SST) and isolate the seawater component of $\delta^{18} \mathrm{O}\left(\delta^{18} \mathrm{O}_{\text {sw-ivc }}\right)$ with an ice volume correction (Lea et al., 2002). Variations in the resultant $\delta^{18} \mathrm{O}_{\text {sw-ivc }}$ are thus directly attributable to variations in local salinity or the salinity $/ \delta^{18} \mathrm{O}$ relationship, reflecting changes in the evaporation-precipitation balance, advection and mixing. $\mathrm{Mg} / \mathrm{Ca}$ ratios were converted to $\mathrm{SST}$ using $\mathrm{Mg} / \mathrm{Ca}=$ $0.34 \exp \left(0.102 * \mathrm{SST}\right.$ ) (Anand et al., 2003), where SST is in ${ }^{\circ} \mathrm{C}$. The seawater 
component of $\delta^{18} \mathrm{O}\left(\delta^{18} \mathrm{O}_{\mathrm{sw}}\right)$ from $39 \mathrm{GGC}$ was calculated using $\mathrm{SST}=14.9-4.8\left(\delta^{18} \mathrm{O}_{\mathrm{c}^{-}}\right.$ $\delta^{18} \mathrm{O}_{\mathrm{sw}}$ ) (Bemis et al., 1998; Thunell et al., 2002). An ice volume correction was applied to the dataset (Lea et al., 2002) and 0.27 ă was added to convert to the VSMOW scale. Our planktonic $\delta^{18} \mathrm{O}$ data are generally similar to the previously published record for G. ruber (white) in core 39GGC (Keigwin and Schlegel, 2002).

Core chronologies are constrained where possible by calibrated accelerator mass spectrometry (AMS) ${ }^{14} \mathrm{C}$ dates. All radiocarbon ages have been (re)calibrated to calendar years before present (yr BP) using the CALIB programme (v. 5.0.1 with the MARINE 04 dataset; (Stuiver et al., 2005), incorporating a 400 yr marine reservoir age correction. Ages were estimated by linear interpolation between age control points.

The chronology employed for 39GGC is based on 11 previously published ${ }^{14} \mathrm{C}$-AMS dates (Keigwin and Schlegel, 2002); Table 1). The two samples from the top $100 \mathrm{~cm}$ are composed of mixed planktonic foraminifera while the nine deeper samples are mono-specific G. ruber. The age model (Fig. 2) suggests that the ${ }^{14} \mathrm{C}$ AMS date at $263 \mathrm{~cm}$ is anomalously old in comparison to the ${ }^{14} \mathrm{C}$-AMS dates either side of it, this may be the result ofmixing with foraminifera from a greater depth in the sediment, and is therefore excluded from the age model calculations. Further ${ }^{14} \mathrm{C}$ AMS dates at $391 \mathrm{~cm}$ and $359 \mathrm{~cm}$ have 1 sigma error bars that overlap suggesting that they are statistically indistinguishable from each other. Based on consideration of the resulting sedimentation rate curve we have removed the age control at $391 \mathrm{~cm}$. The chronology of $28 \mathrm{GGC}$ was generated using six new ${ }^{14} \mathrm{C}$-AMS dates (Table 1) and is shown in Figure 2. Both cores have similarly high sedimentation rates, reflecting the focussing of sediments by the interaction of the DWBC with seabed topography 
(Keigwin and Jones, 1989). Sedimentation rates decrease from $\sim 175 \mathrm{~cm} \mathrm{kyr}^{-1}$ during the early deglaciation to $\sim 15 \mathrm{~cm} \mathrm{kyr}^{-1}$ in the early Holocene.

\section{Results and Discussion}

\subsection{Deglacial northern versus southern sourced flow speed changes}

Sediment supply to the core sites is dominated by transport associated with the DWBC which carries material along the North American margin to create the $\sim 700 \mathrm{~km}$ long BOR (Heezen et al., 1966). As discussed by Bianchi et al. (2001) the velocity structure of the DWBC across the BOR is characterized by decreasing flow speeds away from a fast flowing core. It is also probable that the DWBC changed position and migrated vertically in the water column during past climatic cycles (Bianchi et al., 2001; Evans and Hall, 2008; Evans et al., 2007; Haskell et al., 1991; Johnson et al., 1988; Ledbetter and Balsam, 1985). Therefore, any sedimentological data from the BOR must be viewed in terms of both changing vigor at one or more given localities and position/depth of the DWBC (Evans and Hall, 2008; Evans et al., 2007). During the LGM the DWBC is believed to have shoaled above $2,500 \mathrm{~m}$ at the BOR (Haskell et al., 1991; Johnson et al., 1988), consistent with shallower and reduced NSW formation. The general coarsening trend throughout the deglaciation in the site 39GGC $\overline{\mathrm{SS}}$ record is therefore consistent with a deepening and/or strengthening of the proximal DWBC. This coincides with a general trend towards increasing SST at the BOR (Figure 3C, E). An important observation from this study is the close correspondence, apparent throughout the deglaciation and into the Holocene, between flow speeds changes inferred from the $\overline{\mathrm{SS}}$ at the shallower site 39GGC and the ${ }^{231} \mathrm{~Pa} /{ }^{230} \mathrm{Th}$ record from core OCE326-GGC5 (Figure 4B; hereafter

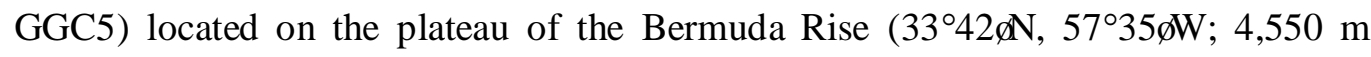


water depth; Figure 1) (McManus et al., 2004). The changes in deep water export traced by ${ }^{231} \mathrm{~Pa} /{ }^{230} \mathrm{Th}$ have been suggested as a kinematic proxy for meridional overturning that potentially demonstrates a significant slow-down of the MOC coincident with the iceberg discharge Heinrich Event $(\mathrm{H})$ 1, and a transient sharp decline in MOC during the YD cold event. The close similarities between the two proxy records suggests that the near-bottom flow speed changes of the NSW component of the DWBC monitored by the 39GGC $\overline{\text { SS }}$ record are closely related to MOC activity (Figure 4B). These deglacial variations in the North Atlantic MOC are also well traced in the benthic $\mathrm{Cd} / \mathrm{Ca}$ paleonutrient record of core EN120-GGC1 $\left(33^{\circ} 40 \mathbf{N}\right.$, $57^{\circ} 37 \mathbf{N y}$; Figure $4 \mathrm{C}$; hereafter GGC1) on the Bermuda Rise at $4,450 \mathrm{~m}$ water depth (Boyle and Keigwin, 1987) and at other deepwater sites (Curry et al., 1988; Duplessy et al., 1988; Keigwin, 2004). The influence of SSW on the Bermuda Rise during the LGM and early deglaciation has recently been supported by ${ }^{143} \mathrm{Nd} /{ }^{144} \mathrm{Nd}$ isotope ratio measurements on the Fe-Mn oxide coatings of planktonic foraminiferal shells in core OCE326-GGC6, the same location as core GGC5 (Figure 1) (Roberts et al., 2010). Together these records suggest that reduced NSW flux and/or shoaling of the DWBC revealed by the $\overline{\mathrm{SS}}$ records allowed nutrient-enriched SSW to shoal and spread northwards in the North Atlantic Ocean. A notable feature of our $\overline{\mathrm{SS}}$ data is the broad-scale divergent flow speeds apparent between changes in northern-sourced DWBC flow speed recorded in core 39GGC and the deeper, SSW influenced core, 28GGC (Figure 3 and 4). The SSW contribution to the deep North Atlantic during the cold events of the last deglaciation (Boyle and Keigwin, 1987; Marchitto et al., 1998a; Marchitto et al., 1998b) is therefore also associated with increased SSW flow vigor on the deep BOR (Figure 4C). This trend is consistent with low resolution grain size records from the South Atlantic that suggest orbital scale 
variability in SSW flow speeds with increased vigor occurring during glacial periods (Allison and Ledbetter, 1982; Ellwood and Ledbetter, 1977; Haskell et al., 1991; Ledbetter, 1979; Ledbetter and Balsam, 1985; Ledbetter and Bork, 1993). Moreover, sedimentological evidence from the Southern Brazilian Basin (Masse et al., 1994) $>4,200 \mathrm{~m}$ water depth suggests increased SSW vigor during cold North Atlantic intervals, similar to the increase in SSW flow speeds observed during both the H1 and YD intervals at 28GGC. Together these observations are suggestive of large-scale oscillations in both the NSW and SSW vigor, coincident with regional climate variations throughout the deglaciation, potentially supporting a óseesawô in the deepwater production between the North Atlantic and Southern Oceans (Broecker, 1998; Crowley, 1992).

\subsection{The early deglacial and Heinrich Event 1}

The contrasting behavior in the $\overline{\mathrm{SS}}$ records is most clearly evident in the 18.515 kyr BP interval. This interval incorporates $\mathrm{H} 1$ at $\sim 16.8 \mathrm{kyr}$ BP, characterized by large IRD deposits in the North Atlantic (Bard et al., 2000; Bond et al., 1992; Hemming, 2004). The associated freshwater input reduced the density of the surface waters and has been associated with substantially reduced NSW production (Keigwin and Lehman, 1994; Rickaby and Elderfield, 2005; Robinson et al., 2005; Vidal et al., 1997; Vidal et al., 1998; Willamowski and Zahn, 2000; Zahn et al., 1997; Zahn and Stüber, 2002). Freshening of the surface ocean recorded in the $\delta^{18} \mathrm{O}_{\text {sw-ivc }}$ at 39 GGC, 17-16.3 kyr BP (Figure 3D), corresponds to the timing associated with H1, suggesting that some freshwater from the eastern outlets of the Laurentide Ice Sheet (Bond et al., 1992) reached as far south as the BOR. The low salinity event at the 39GGC has no counterpart in the Gulf of Mexico or Caribbean (Flower et al., 2004; 
Schmidt et al., 2004) supporting a freshwater pulse delivered to the North Atlantic via a more northerly outlet rather than the Mississippi River. During the initial decrease, from $~ 18.5-17 \mathrm{kyr} \mathrm{BP}$, in the DWBC flow speeds recorded at 39GCGC, SST at the site increases by approximately $1^{\circ} \mathrm{C}$. As suggested for lower latitudes (Flower et al., 2004; Schmidt et al., 2004), this early warming prior to H1, likely reflects regional heat retention at the BOR as the MOC slowed. While the reduction in flow speed at $\sim 3,000 \mathrm{~m}$ suggests shallower and/or weaker NSW production, the $\overline{\mathrm{SS}}$ record also shows small-scale variability within the $\mathrm{H} 1$ interval suggesting that the overall MOC was subdued at this time rather than totally absent.

During the interval 18.5-15 kyr BP the deepest core, 28GGC, was distant from the influence of the shoaled northern-sourced DWBC, but coarse $\overline{\mathrm{SS}}$ values are suggestive of significant current activity below $\sim 4,000 \mathrm{~m}$, which coincide with the presence of nutrient enriched deepwater indicative of a Southern Ocean source (Figure 4C). This northward flowing SSW was likely entrained and re-circulated in the sub-tropical gyre (Hogg, 1983) before being transported as a vigorous flow back southwards over the BOR (Figure 1). Vigorous SSW circulation is also implied during $\mathrm{H} 1$ by $\Delta^{14} \mathrm{C}$ water column profiles in the North Atlantic (Robinson et al., 2005), which has shown deep water in the North Atlantic during H1 to have the same offset from the atmosphere as the southern sourced end member (Goldstein et al., 2001).

\subsection{The Bølling/Allerød}

The H1 interval of increased SSW flow vigor begins to show a reversing trend corresponding to the onset of the Bølling-Allerød (B/A) warm period, when ${ }^{231} \mathrm{~Pa} /{ }^{230} \mathrm{Th}$ (Gherardi et al., 2005; McManus et al., 2004), benthic $\mathrm{Cd} / \mathrm{Ca}$ (Boyle and Keigwin, 1987) and decreasing $\varepsilon_{\mathrm{Nd}}$ values at GG1 (Roberts et al., 2010), suggest a 
reinvigoration of the MOC. This increase is consistent with the rising trend recorded in the DWBC flow speed at site 39GGC (Fig. 4). In the tropics the MOC reinvigoration is represented by a decrease in salinity as the highly saline water is exported northwards (Schmidt et al., 2004). Corresponding high background $\delta^{18} \mathrm{O}_{\text {sw- }}$ ivc (salinity) values are recorded at 39GGC following the initial freshwater pulse of H1 (Fig. 3 D). This increase in salinity was the likely effect of (i) the removal of the influence of the freshwater pulse at the BOR associated with $\mathrm{H} 1$ (ii) a reinvigorated Gulf Stream transport of warm and saline water northwards from the tropics over the study site and (iii) changes in the hydrological cycle which accompany the transition from a significantly reduced to an increasingly active MOC (Zhang and Delworth, 2005). These changes support the suggestion that B/A warming resulted primarily from reinvigoration of the oceanic heat transport as MOC increased (Schmidt et al., 2004). As highlighted by (McManus et al., 2004) the timing of the MOC reinvigoration occurred shortly before meltwater pulse 1a (MWP-1a), the most extreme rapid deglacial rise in global sea level $(\sim 20 \mathrm{~m})$ and reduction of continental ice volume, which recent studies have dated at 14.6 kyr BP (Deschamps et al., 2009; Hanebuth et al., 2000); this is in contrast to the Barbados coral age of $~ 14.1-13.6 \mathrm{ka}$ (Stanford et al., 2006) for which there is some uncertainty (e.g. Bard et al., 2010; Deschamps et al., 2009). There has been considerable debate surrounding the origin of MWP-1a with some studies ruling out a Northern Hemisphere source, advocating instead an Antarctic origin (Clark, 2002; Weaver et al., 2003). Records from the Gulf of Mexico (e.g. Aharon, 2003; Flower et al., 2004) indicate substantial freshening during MWP-1a, suggesting a Laurentide ice-sheet source, delivered via the Mississippi River, for MWP-1A; although geochemical constraints limit the Laurentide ice-sheet contribution to MWP-1A to less than $~ 30 \%$ (Carlson, 2009), 
2009). Our data therefore support the view that MWP-1a had, at least in part, a Northern Hemisphere origin, because a small low $\delta^{18} \mathrm{O}_{\text {sw-ivc }}$ (salinity) pulse is seen at 39GGC coincident with the decreasing salinities recorded in the Gulf of Mexico (Flower et al., 2004). The small amplitude of the signal at the BOR may be a result of the proposed hyperpycnal discharge of MWP-1A into the Gulf of Mexico (Aharon, 2003; Aharon, 2006), such that the strong mixing with seawater would have reduced its influence on the salinity profile at the BOR (Aharon, 2003; Tarasov and Peltier, 2005). The transient increases in $\delta^{18} \mathrm{O}_{\text {sw-ivc }}$ values (salinity) at the BOR at $\sim 14.3 \mathrm{ka}$ and $\sim 13.6$ ka were likely caused by the temporary rerouting of meltwater discharge from the Mississippi to the eastern outlets (Thornalley et al., 2010). Minimum values in $\delta^{18} \mathrm{O}_{\text {sw-ivc }}$ (salinity) at the BOR between 15-13 ka coincide with peak meltwater discharge into the Gulf of Mexico (Flower et al., 2004), providing strong evidence that meltwater reached the open North Atlantic and entered the subtropical gyre. It appears probable that the meltwater discharged to the North Atlantic, via the Mississippi River and eastern outlets helped q́rimeôthe North Atlantic ready for later pulses of freshwater that are thought to be responsible for the YD cooling (Keigwin et al., 1991).

\subsection{The Younger Dryas}

Increased ${ }^{231} \mathrm{~Pa} /{ }^{230} \mathrm{Th}$ (Gherardi et al., 2005; McManus et al., 2004), $\mathrm{Cd} / \mathrm{Ca}$ (Boyle and Keigwin, 1987) and decreased $\Delta^{14} \mathrm{C}$ (Robinson et al., 2005) have been used to infer a reduction in the MOC and increased penetration of SSW into the North Atlantic during the YD cold event. This is consistent with our paleocurrent records that show that the flow speeds associated with the rate and/or position of the DWBC decreased at $\sim 13 \mathrm{kyr} \mathrm{BP}$ at, at the same time SSTô show a slight $\left(\sim 0.5^{\circ} \mathrm{C}\right)$ cooling at the BOR, indicative of reduced surface heat transport as a result of a weaker MOC. 
The slight salinity increase at this time likely reflects a reduction in regional meltwater input and changes in the hydrological cycle (Schmidt et al., 2004). During this interval SSW at the deeper site again shows generally contrasting flow speeds to the shallower site, indicating increased vigor. As also suggested in the GGC5 ${ }^{231} \mathrm{~Pa} /{ }^{230} \mathrm{Th}$ record, the flow speed changes recorded during the YD are substantially less marked than those observed during H1. Indeed it is reassuring that the relative magnitudes of each of the recorded circulation changes are so similar.

\subsection{The Early Holocene}

As zero age samples are not available from either 39 GGC or 28 GGC we are unable to fully assess how representative the general Holocene $\overline{\mathrm{SS}}$ pattern is of the modern flow regime. During the early Holocene, at about $\sim 9.5 \mathrm{kyr} \mathrm{BP}$, the $\overline{\mathrm{SS}}$ records show a maximum at the shallower site $39 \mathrm{GGC}$ and a minimum at the deeper site $28 \mathrm{GGC}$, coincident with high ventilation rates and vigorous NADW production in the deep North Atlantic (Boyle and Keigwin, 1987; McManus et al., 2004). This difference suggests that the fast flowing core of the DWBC was likely close to its present day position, influencing depth from 3,000 $\mathrm{m}$ down to 4,100 $\mathrm{m}$ (Stahr and Sanford, 1999) from that time.

\section{Conclusions}

This study demonstrates that an $\overline{\mathrm{SS}}$ near-bottom flow record from $\sim 3,000 \mathrm{~m}$ (site 39GGC) on the BOR provide a good direct comparison with/proxy for MOC activity, as it correlates well to the ${ }^{231} \mathrm{~Pa} /{ }^{230} \mathrm{Th}$ circulation tracer from the Bermuda Rise irrespective of climate state. This study highlights the differing flow speed behaviour between $\sim 3,000 \mathrm{~m}$ and $>4,000 \mathrm{~m}$ water depth in the subtropical North 
Atlantic during the last deglaciation, and supports the notion of a bipolar seesaw in deep water production. During this interval SSTô at the BOR are primarily affected by the strength of the Gulf Stream, in addition to the effects of heat retention in the tropical Atlantic prior to and during H1. Salinity reconstructions at the BOR reflect a combination of meltwater inputs, hydrological changes and variations in the MOC, and show the presence of a number of meltwater signals that can be traced to both the southern and eastern outlets of the LIS. A low salinity anomaly coincident with H1 suggests meltwater from the eastern outlets reached as far south as the BOR. It is shown that during the B/A a meltwater signal influences the BOR from the GOM consistent with a Northern Hemisphere origin for at least part of MWP-1a which may have óprimedôthe North Atlantic ready for the YD.

Acknowledgements. We thank H. Elderfield for laboratory support and G. Bianchi and S. Barker for useful discussions. L. Keigwin is thanked for generously providing sediment samples. This work was supported by funding from the U.K. National Environmental Research Council (NERC) Rapid Programme and NERC Radiocarbon Laboratory, UK.

\section{References}

Adkins, J.F., Mc Intyre, K. and Schrag, D.P., 2002. The Salinity, Temperature, and $\delta^{18} \mathrm{O}$ of the Glacial Deep Ocean. Science, 298: 1769-1773.

Adkins, J.F. and Schrag, D.P., 2003. Reconstructing Last Glacial Maximum bottom water salinities from deep-sea sediment pore fluid profiles. Earth and Planetary Science Letters, 216(1-2): 109-123. 
Aharon, P., 2003. Meltwater flooding events in the Gulf of Mexico revisited: Implications for rapid climate changes during the last deglaciation. Paleoceanography, 18(4): 1079, 10.1029/2002PA000840.

Aharon, P., 2006. Entrainment of meltwaters in hyperpycnal flows during deglaciation superfloods in the Gulf of Mexico. Earth and Planetary Science Letters, 241(1-2): 260-270.

Alley, R.B. et al., 1993. Abrupt increase in Greenland snow accumulation at the end of the Younger Dryas event. Nature, 362: 527-529.

Allison, E. and Ledbetter, M.T., 1982. Timing of bottom-water scour recorded by sedimentological parameters in the Southern Australian Basin. Marine Geology, 46: 131-147.

Anand, P., Elderfield, H. and Conte, M.H., 2003. Calibration of Mg/Ca thermometry in planktonic foraminifera from a sediment trap time series. Paleoceanography, 18(2): 1050, 10.1029/2002PA000846.

Bard, E., Hamelin, B. and Delanghe-Sabatier, D., 2010. Deglacial meltwaterpulse 1B and Younger Dryas sea levels revisited with boreholes at Tahiti. Science, doi:10.1126/science.1180557.

Bard, E., Rostek, F., Turon, J.L. and Gendreau, S., 2000. Hydrological impact of Heinrich events in the subtropical northeast Atlantic. Science, 289: 1321-1324.

Barker, S., Cacho, I., Benway, H. and Tachikawa, K., 2005. Planktonic foraminiferal $\mathrm{Mg} / \mathrm{Ca}$ as a proxy for past oceanic temperatures: a methodological overview and data compilation for the Last Glacial Maximum. Quaternary Science Reviews, 24: 821-834. 
Barker, S., Greaves, M. and Elderfield, H., 2003. A study of cleaning procedures used for foraminiferal $\mathrm{Mg} / \mathrm{Ca}$ paleothermometry. Geochemistry, Geophysics, Geosystems, 4(9): 8407, doi:10.1029/2003GC000559.

Bemis, B.E., Spero, H., Bijma, J. and Lea, D.W., 1998. Reevaluation of the oxygen isotopic composition of planktonic foraminifera: experimental results and revised paleotemperature equations. Paleoceanography, 13: 150-160.

Bianchi, G.G., Hall, I.R., McCave, I.N. and Joseph, L., 1999. Measurement of the sortable silt current speed proxy using the Sedigraph 5100 and Coulter Multisizer IIe: precision and accuracy. Sedimentology, 46: 1001-1014.

Bianchi, G.G., Vautravers, M. and Shackleton, N.J., 2001. Deep flow variability under apparently stable North Atlantic Deep Water production during the last interglacial of the subtropical NW Atlantic. Paleoceanography, 16(3): 306316.

Blunier, T. and Brook, E.J., 2001. Timing of millennial-scale climate change in Antarctica and Greenland during the last glacial period. Science, 291: 109112.

Bond, G. et al., 1992. Evidence for massive discharges of icebergs into the North Atlantic ocean during the last glacial period. Nature, 360: 245-249.

Boyle, E.A. and Keigwin, L., 1987. North Atlantic thermohaline circulation during the past 20,000 years linked to high-latitude surface temperature. Nature, 330(6143): 35-40.

Boyle, E.A. and Keigwin, L.D., 1985. Comparison of Atlantic and Pacific paleochemical records for the last 215,000 years: changes in deep ocean circulation and chemical inventories. Earth and Planetary Science Letters, 76: 135-150. 
Broecker, W., 1991. The Great Ocean conveyor. Oceanography, 4: 79-89.

Broecker, W.S., 1998. Paleocean circulation during the last deglaciation: A bipolar seesaw? Paleoceanography, 13: 119-121.

Broecker, W.S., 2006. Was the Younger Dryas Triggered by a Flood? Science, 312: $1146-1148$.

Broecker, W.S., Peteet, D.M. and Rind, D., 1985. Does the ocean-atmosphere system have more than one stable mode of operation? Nature, 315: 21-26.

Came, R.E., Oppo, D.W. and Curry, W.B., 2003. Atlantic Ocean circulation during the Younger Dryas: Insights from a new $\mathrm{Cd} / \mathrm{Ca}$ record from the western subtropical South Atlantic. Paleoceanography, 18(4): 1086, 10.1029/2003PA000888.

Carlson, A.E., 2009. Geochemical constraints on the Laurentide Ice Sheet contribution to Meltwater Pulse 1A. Quaternary Science Reviews, 28(17-18): $1625-1630$.

Carlson, A.E. et al., 2008. Subtropical Atlantic salinity variability and Atlantic meridional circulation during the last deglaciation. Geology, 36(12): 991-994.

Chappellaz, J. et al., 1993. Synchronous changes in atmospheric $\mathrm{CH}_{4}$ and Greenland climate between 40 and 8 kyr BP. Nature, 366: 443-445.

Clark, P.U., Mitrovica, J. X., A Milne, G. A., A Tamisiea, M. E., 2002. Sea-Level Fingerprinting as a Direct Test for the Source of Global Meltwater Pulse IA. Science, 295(5564): 2438-2441.

Clark, P.U., Pisias, N.G., Stocker, T.F. and Weaver, A.J., 2002. The role of the thermohaline circulation in abrupt climate change. Nature, 415: 863-869.

Crowley, T.J., 1992. North Atlantic deep water cools the southern hemisphere. Paleoceanography, 7: 489-497. 
Curry, W.B., Duplessy, J.C., Labeyrie, L.D. and Shackleton, N.J., 1988. Changes in the distribution of $\delta^{13} \mathrm{C}$ of deep water $\Sigma \mathrm{CO}_{2}$ between the last glaciation and the Holocene. Paleoceanography, 3(3): 317-341.

Curry, W.B. and Oppo, D.W., 2005. Glacial water mass geometry and the distribution of $\delta^{13} \mathrm{C}$ of $\Sigma \mathrm{CO}_{2}$ in the western Atlantic Ocean. Paleoceanography, 20(1): PA1017, 10.1029/2004PA001021.

Deschamps, P. et al., 2009. Synchroneity of Meltwater Pulse 1A and the Bølling onset: New evidence from the IODP "Tahiti Sea-Level" Expedition. Geophysical Research Abstracts, 11: EGU2009-10233.

Dickson, R.R. and Brown, J., 1994. The production of North Atlantic Deep Water sources, rates, and pathways. Journal of Geophysical Research, C99(6): 12319-12341.

Duplessy, J.C. et al., 1988. Deep water source variations during the last climatic cycle and their impact on the global deep water circulation. Paleoceanography, 3(3): 343-360.

Ellwood, B.B. and Ledbetter, M.T., 1977. Antarctic bottom water fluctuations in Vema Channel - effects of velocity changes on particle alignment and size. Earth and Planetary Science Letters, 35(2): 189-198.

Evans, H.K. and Hall, I.R., 2008. Deepwater circulation on Blake Outer Ridge (western North Atlantic) during the Holocene, Younger Dryas, and Last Glacial Maximum. Geochemistry Geophysics Geosystems, 9.

Evans, H.K., Hall, I.R., Bianchi, G.G. and Oppo, D.W., 2007. Intermediate Water links to Deep Western Boundary Current variability in the subtropical NW Atlantic during Marine Isotope Stages 5 and 4. Paleoceanography, 22: PA3209, doi:10.1029/2006PA001409. 
Flower, B.P., Hastings, D.W., Hill, H.W. and Quinn, T.M., 2004. Phasing of deglacial warming and Laurentide Ice Sheet meltwater in the Gulf of Mexico. Geology, 32(7): 597-600.

Gherardi, J.-M. et al., 2005. Evidence from the Northeastern Atlantic basin for variability in the rate of the meriodional overtuning circulation through the last deglaciation. Earth and Planetary Science Letters, 240: 710-723.

Goldstein, S.J., Lea, D.W., Chakraborty, S., Kashgarian, M. and Murrell, M.T., 2001. Uranium-series and radiocarbon geochronology of deep-sea corals: implications for Southern Ocean ventilation rates and the oceanic carbon cycle. Earth and Planetary Science Letters, 193: 167-182.

Grootes, P.M. and Stuiver, M., 1997. Oxygen 18/16 variability in Greenland snow and ice with $10^{-3}$ - to $10^{5}$-year time resolution. Journal of Geophysical Research, C102(C12): 26455-26470.

Grootes, P.M.a.S., M., 1997. 18O/16O Variability in Greenland snow and ice with 103 to 105 yr time resolution. Journal of Geophysical Research Special Issue on The GISP2/GRIP Ice Cores, 102(26): 26,445-26,470.

Hanebuth, T., Stattegger, K. and Grootes, P.M., 2000. Rapid flooding of the Sunda Shelf: a late-glacial sea-level record. Science, 288: 1033-1035.

Haskell, B.J., Johnson, T.C. and Showers, W.J., 1991. Fluctuations in deep western North Atlantic circulation on the Blake Outer Ridge during the last deglaciation. Paleoceanography, 6: 21-31.

Heezen, B.C., Hollister.C.D. and Ruddiman, W.F., 1966. Shaping of continental rise by deep geostrophic contour currents. Science, 152(3721): 502-508. 
Hemming, S.R., 2004. Heinrich Events: Massive late Pleistocene detritus layers of the North Atlantic and their global climate imprint. Reviews of Geophysics, 42: 2003RG000128.

Hogg, N.G., 1983. A note on the deep circulation of the western North-Atlantic - its nature and causes. Deep-Sea Research Part a-Oceanographic Research Papers, 30(9): 945-961.

Hüls, M. and Zahn, R., 2000. Millennial-scale sea surface temperature variability in the western tropical North Atlantic from planktonic foraminiferal census counts. Paleoceanography, 15(6): 659-678.

Johnsen, S.J., Dansgaard, W., Clausen, H.B. and Langway, C.C., 1972. Oxygen isotope profiles through Antarctic and Greenland ice sheets. Nature, 235: 429434.

Johnson, T.C., Lynch, E.L., Showers, W.J. and Palczuc, N.C., 1988. Pleistocene fluctuations in the western boundary undercurrent on the Blake Outer Ridge. Paleoceanography, 3: 191-207.

Keigwin, L.D., 2004. Radiocarbon and stable isotope constraints on Last Glacial Maximum and Younger Dryas ventilation in the western North Atlantic. Paleoceanography, 19(4): PA4012, 10.1029/2004PA001029.

Keigwin, L.D., Curry, W.B., Lehman, S.J. and Johnsen, S., 1994. The role of the deep ocean in North Atlantic climate change between 60 and 130 kyr ago. Nature, $371: 323-326$

Keigwin, L.D. and Jones, G.A., 1989. Glacial-Holocene stratigraphy, chronology, and paleoceanographic observations on some North Atlantic sediment drifts. Deep - Sea Research Part I - Oceanographic Research Papers, 36: 845-867. 
Keigwin, L.D., Jones, G.A. and Lehman, S.J., 1991. Deglacial meltwater discharge, North Atlantic deep circulation and abrupt climate change. Journal of Geophysical Research, C96: 16811-16826.

Keigwin, L.D. and Lehman, S.J., 1994. Deep circulation change linked to Heinrich Event-1 and Younger Dryas in a mid-depth North Atlantic core. Paleoceanography, 9: 185-194.

Keigwin, L.D. and Schlegel, M.A., 2002. Ocean ventilation and sedimentation since the glacial maximum at $3 \mathrm{~km}$ in the western North Atlantic. Geochemistry, Geophysics, Geosystems, 3(6): 1034, doi:10.1029/2001GC000283.

Lea, D.W., Martin, P.A., Pak, D.K. and Spero, H.J., 2002. Reconstructing a 350 ky history of sea level using planktonic $\mathrm{Mg} / \mathrm{Ca}$ and oxygen isotope records from a Cocos Ridge core. Quaternary Science Reviews, 21(1-3): 283.

Ledbetter, M.T., 1979. Fluctuations of Antarctic bottom water velocity in the Vema Channel during the last 160,000 years. Marine Geology, 33(1-2): 71-89.

Ledbetter, M.T. and Balsam, W.L., 1985. Paleoceanography of the deep western boundary undercurrent on the north-American continental-margin for the past 25000 yrs. Geology, 13(3): 181-184.

Ledbetter, M.T. and Bork, K.R., 1993. Post Miocene fluctuations of Antarctic bottom water paleospeed in the southwest Atlantic Ocean. Deep-Sea Research Part IITopical Studies in Oceanography, 40(4-5): 1057-1071.

Lowe, J.J. et al., 2008. Synchronisation of palaeoenvironmental events in the North Atlantic region during the Last Termination: a revised protocol recommended by the INTIMATE group. Quaternary Science Reviews, 27(1-2): 6-17.

Marchitto, T.M., Curry, W.B. and Oppo, D., 1998a. Millennial-scale changes in North Atlantic circulation since the last glaciation. Nature, 393: 557-561. 
Marchitto, T.M., Curry, W.B. and Oppo, D.W., 1998b. Millennial-scale changes in North Atlantic circulation since the last glaciation. Nature, 393(6685): 557561.

Masse, L., Faugeres, J.C., Bernat, M., Pujos, A. and Mezerais, M.L., 1994. A 600,000-year record of Antarctic Bottom Water activity inferred from sediment textures and structures in a sediment core from the Southern Brazil Basin. Paleoceanography, 9(6): 1017-1026.

Mauritzen, C., 1996. Production of dense overflow waters feeding the North Atlantic across the Greenland-Scotland Ridge. 1. Evidence for a revised circulation scheme. Deep-Sea Research Part I - Oceanographic Research Papers, 43(6): 769-806.

McCave, I.N. and Hall, I.R., 2006. Size sorting in marine muds: Processes, pitfalls, and prospects for paleoflow-speed proxies. Geochem. Geophys. Geosyst., 7(10): Q10N05.

McManus, J.F., Francois, R., Gherardi, J.M., Keigwin, L.D. and Brown-Leger, S., 2004. Collapse and rapid resumption of Atlantic meridional circulation linked to deglacial climate changes. Nature, 428: 834-837.

Oppo, D.W. and Lehman, S.J., 1993. Middepth circulation of the subpolar North Atlantic during the Last Glacial Maximum. Science, 259: 1,148ї 1,152.

Raymo, M.E. et al., 2004. Stability of North Atlantic water masses in face of pronounced climate variability during the Pleistocene. Paleoceanography, 19: PA2008, 10.1029/2003PA000921.

Rickaby, R.E.M. and Elderfield, H., 2005. Evidence from the high-latitude North Atlantic for variations in Antarctic Intermediate water flow during the last 
deglaciation. Geochemistry Geophysics Geosystems, 6(5): Q05001, 10.1029/2004GC000858.

Roberts, N.L., Piotrowski, A.M., McManus, J.F. and Keigwin, L.D., 2010. Synchronous Deglacial Overturning and Water Mass Source Changes. Science, 327(5961): 75-78.

Robinson, L.F. et al., 2005. Radiocarbon Variability in the Western North Atlantic During the Last Deglaciation. Science, 310: 1469-1473.

Rühlemann, C., Mulitza, S., Müller, P.J., Wefer, G. and Zahn, R., 1999. Warming of the tropical Atlantic Ocean and slowdown of thermohaline circulation during the last deglaciation. Nature, 402: 511-514.

Schmidt, M.W., Spero, H.J. and Lea, D.W., 2004. Links between salinity variation in the Caribbean and North Atlantic thermohaline circulation. Nature, 428: 160163.

Schmitz, W.J., Jr. and McCartney, M.S., 1993. On the North Atlantic circulation. Reviews of Geophysics, 31: 29-49.

Stahr, F.R. and Sanford, T.B., 1999. Transport and bottom boundary layer observations of the North Atlantic Deep Western Boundary Current at the Blake Outer Ridge. Deep-Sea Research Part II-Topical Studies in Oceanography, 46(1-2): 205-243.

Stanford, J.D. et al., 2006. Timing of meltwater pulse 1a and climate responses to meltwater injections. Paleoceanography, 21(4): PA4103, 10.1029/2006PA001340.

Stuiver, M., Reimer, P.J. and Reimer, R.W., 2005. CALIB 5.0. [WWW program and documentation]. . 
Tarasov, L. and Peltier, W.R., 2005. Arctic freshwater forcing of the Younger Dryas cold reversal. Nature, 435: 662-665.

Thornalley, D.J.R., McCave, I.N. and Elderfield, H., 2010. Freshwater input and abrupt deglacial climate change in the North Atlantic. Paleoceanography, 25, PA1201: doi:10.1029/2009PA001772.

Thunell, R.C., Poli, M.S. and Rio, D., 2002. Changes in deep and intermediate water properties in the western North Atlantic during marine isotope stages 11-42: Evidence from ODP Leg 172. Marine Geology, 189(1-2): 63-77.

Vidal, L. et al., 1997. Evidence for changes in the North Atlantic Deep Water linked to meltwater surges during the Heinrich events. Earth and Planetary Science Letters, 146(1-2): 13-27.

Vidal, L., Labeyrie, L. and van Weering, T.C.E., 1998. Benthic $\delta^{18} \mathrm{O}$ records in the North Atlantic over the last glacial period (60-10 kyr): Evidence for brine formation. Paleoceanography, 13(3): 245-251.

Weatherly, G.L. and Kelley, E.A., 1984. Two views of the cold filament. Journal of Physical Oceanography, 15: 245-251.

Weaver, A.J., Saenko, O.A., Clark, P.A. and Mitrovica, J.X., 2003. Meltwater Pulse 1A from Antarctica as a Trigger of the Bolling-Allerod Warm Interval. Science, 299(5613): 1709-1713.

Weldeab, S., Schneider, R.R. and Kölling, M., 2006. Deglacial sea surface temperature and salinity increase in the western tropical Atlantic in synchrony with high latitude climate instabilities. Earth and Planetary Science Letters, 241: 699-706. 
Willamowski, C. and Zahn, R., 2000. Upper ocean circulation in the glacial North Atlantic from benthic foraminiferal isotope and trace element fingerprinting. Paleoceanography, 15(5): 515-527.

Zahn, R. et al., 1997. Thermohaline instability in the North Atlantic during meltwater events: Stable isotope and ice-rafted detritus records from core SO75-26KL, Portuguese margin. Paleoceanography, 12(5): 696-710.

Zahn, R. and Stüber, A., 2002. Suborbital intermediate water variability inferred from paired benthic foraminiferal $\mathrm{Cd} / \mathrm{Ca}$ and $\delta^{13} \mathrm{C}$ in the tropical West Atlantic. Earth and Planetary Science Letters, 200: 191-205.

Zhang, R. and Delworth, T.L., 2005. Simulated Tropical Response to a Substantial Weakening of the Atlantic Thermohaline Circulation. Journal of Climate, 18: $1853-1860$. 


\section{Figure legends}

Figure 1. Map showing the pathway of recirculating Southern Sourced Water (SSW, thick black line) in the NW Atlantic (adapted fromWeatherly and Kelley, 1984). The location of sediment cores KNR 140/2 39GGC and 28GGC, along with GGC1, 5 and 6 are highlighted. The Blake Outer Ridge (BOR), Bermuda Rise (BR), Hatteras Abyssal Plain (HAP) and Sohm Abyssal Plain (SAP) and position of the Deep Western Boundary Current (DWBC) are shown.

Figure 2. Core chronology. Various isotope records are shown versus age. (A) GISP2 $\delta^{18} \mathrm{O}$ (Grootes and Stuiver, 1997) (B) a new SST record for core KNR 140/239GGC derived from $\mathrm{Mg} / \mathrm{Ca}$ measurements; (C) a new planktonic $\delta^{18} \mathrm{O}$ record for KNR 140/2-39GGC (2,985 m water depth) overlies the previously published lower resolution $\delta^{18} \mathrm{O}$ record of Keigwin and Schlegel (2002) at the site; (D) planktonic $\delta^{18} \mathrm{O}$ for core KNR 140/2-28GGC (4,211 m water depth) (Keigwin et al., 1994); (E) planktonic $\delta^{18} \mathrm{O}$ for EN120-GGC1 (4,450 m water depth) (Keigwin et al., 1991); (F) planktonic $\delta^{18} \mathrm{O}$ for OCE326-GGC5 (grey line, $4550 \mathrm{~m}$ water depth) (McManus et al., 2004). All isotope measurements were carried out on the planktonic foraminifera species G. ruber with the exception of OCE326-GGC5 (McManus et al., 2004), which is derived from $G$. inflata. The positions of AMS dates are shown by the triangles, while the dashed lines show additional tie points used where no AMS dates where available. The AMS dates from KNR 140/2-39GGC are taken from (Keigwin and Schlegel, 2002) and the AMS dates for KNR 140/2-28GGC are newly presented in this study (see Table 1). The AMS dates for EN120-GGC1 are taken from Came et 
al., (2003) and the AMS dates for OCE326-GGC5 are taken from (McManus et al., 2004)..

Figure 3. (A) GISP2 $\delta^{18} \mathrm{O}$ (Grootes, 1997); (B) planktonic $\delta^{18} \mathrm{O}$ for core 39GGC (2,975 m water depth) measured on the planktonic foraminifera G. ruber; (C); (D) The derived ice volume corrected $\delta^{18} \mathrm{O}$ of seawater $\left(\delta^{18} \mathrm{O}_{\text {sw-ivc }}\right)$ for 39 GGC representative of local surface salinity changes at the BOR. (E) $\overline{\mathrm{SS}}$ for core 39GGC and (F) $\overline{\mathrm{SS}}$ for core $28 \mathrm{GGC}(4,211 \mathrm{~m}$ water depth). The core sites are under the influence of the southward flowing DWBC which transports material from the eastern Canadian and US margin, and therefore the records for each site are normalized about a common mean set equal to zero in order to eliminate the effect of the proximity component to the continental margin (Haskell et al., 1991). Positions of Heinrich Event 1 (H1), the Bølling-Allerød (B/A) and the Younger Dryas (YD) are indicated.

Figure 4. Comparison of sedimentary records from the subtropical Atlantic with trace metal and polar ice core records spanning the interval 20-5 kyr BP. (A) Greenland temperature (GISP2 $\delta^{18} \mathrm{O}$, Grootes, 1997); (B) Smoothed $\overline{\mathrm{SS}}$ for core 39GGC (black line, 2,975 m water depth) from the BOR and the ${ }^{231} \mathrm{~Pa} /{ }^{230} \mathrm{Th}$ for core OCE326-GGC5 (grey line, 4,550 m water depth) (McManus et al., 2004) from the Bermuda Rise; (C) Smoothed $\overline{\text { SS }}$ for core 28GGC (black line, 4,211 m water depth) from the BOR and the $\mathrm{Cd} / \mathrm{Ca}$ for core $\mathrm{GGC1}$ (grey line, note revered scale) (Boyle and Keigwin, 1987); (D) $\varepsilon_{\mathrm{Nd}}$ for core GGC6 (note revered scale, 4,550 m water depth) from the Bermuda Rise (Roberts et al., 2010); (E) Antarctic tempereture(Byrd $\delta^{18} \mathrm{O}$, Blunier and Brook, 2001; Johnsen et al., 1972)The $\overline{\text { SS }}$ values are shown on a 
common variance scale. We slightly altered the Keigwin et al. (1991) chronology of core GGC1 utilising three additional ${ }^{14} \mathrm{C}$-AMS from Came et al. (2003) and further graphic correlation to the nearby planktonic $\delta^{18} \mathrm{O}$ record of GGC5. Positions of Heinrich Event 1 (H1), the Bølling/Allerød (B/A) and the Younger Dryas (YD) are indicated. 
Table 1. Radio carbon dating results from KNR 140/2-28GGC, with a marine reservoir correction of 400 yr. Obtained from CALIB v5.0 (Stuiver et al., 2005).

\begin{tabular}{|l|c|c|c|c|c|c|}
\hline $\begin{array}{l}\text { Laboratory } \\
\text { Number }\end{array}$ & Material & $\begin{array}{c}\text { Depth } \\
(\mathrm{cm})\end{array}$ & $\begin{array}{c}{ }^{14} \text { C Age yr } \\
\text { BP }\end{array}$ & $\begin{array}{c}\text { Error Age } \\
\pm 1 \sigma \text { yr BP }\end{array}$ & $\begin{array}{c}\text { Calendar } \\
\text { Age yr }\end{array}$ & Reference \\
\hline 39GGC & & & & & & \\
NOSAM-7139 & mixed & $6-8$ & 1980 & 35 & 1543 & $\mathrm{a}$ \\
NOSAM-7129 & mixed & $62-64$ & 6620 & 40 & 7166.5 & $\mathrm{a}$ \\
NOSAM-7141 & G. ruber & $126-128$ & 11350 & 50 & 12889 & $\mathrm{a}$ \\
NOSAM-16368 & G. ruber & $174-176$ & 13250 & 70 & 15353 & $\mathrm{a}$ \\
NOSAM-26405 & G. ruber & $206-208$ & 13900 & 80 & 16034.5 & $\mathrm{a}$ \\
NOSAM-26406 & G. ruber & $234-236$ & 14500 & 100 & 16810 & $\mathrm{a}$ \\
NOSAM-26407 & G. ruber & $262-264$ & 15150 & 130 & 17836 & $\mathrm{a}$ \\
NOSAM-26408 & G. ruber & $294-296$ & 15000 & 80 & 17676.5 & $\mathrm{a}$ \\
NOSAM-26409 & G. ruber & $358-360$ & 15550 & 80 & 18593 & $\mathrm{a}$ \\
NOSAM-26410 & G. ruber & $390-392$ & 15700 & 90 & 18688 & $\mathrm{a}$ \\
NOSAM-26432 & G. ruber & $429-432$ & 16900 & 75 & 19730.5 & $\mathrm{a}$ \\
& & & & & & \\
28GGC & & & & & & \\
SUERC-7701 & G. ruber & $24-25$ & 9405 & 29 & 10323.5 & $\mathrm{~b}$ \\
SUERC-7702 & G. ruber & $48-49$ & 10924 & 11.6 & 12438.5 & $\mathrm{~b}$ \\
SUERC-7703 & mixed & $88-89$ & 12891 & 11.4 & 14595.5 & $\mathrm{~b}$ \\
SUERC-7704 & mixed & $152-157$ & 13613 & 45 & 15632.5 & $\mathrm{~b}$ \\
SUERC-7705 & mixed & $207.5-209$ & 14303 & 48 & 16558 & $\mathrm{~b}$ \\
SUERC-7707 & mixed & $261-263$ & 14664 & 51 & 17037 & $\mathrm{~b}$ \\
\hline
\end{tabular}

Note, Reference a = Keigwin and Schlegel (2002), b = this study 
Figure 1.

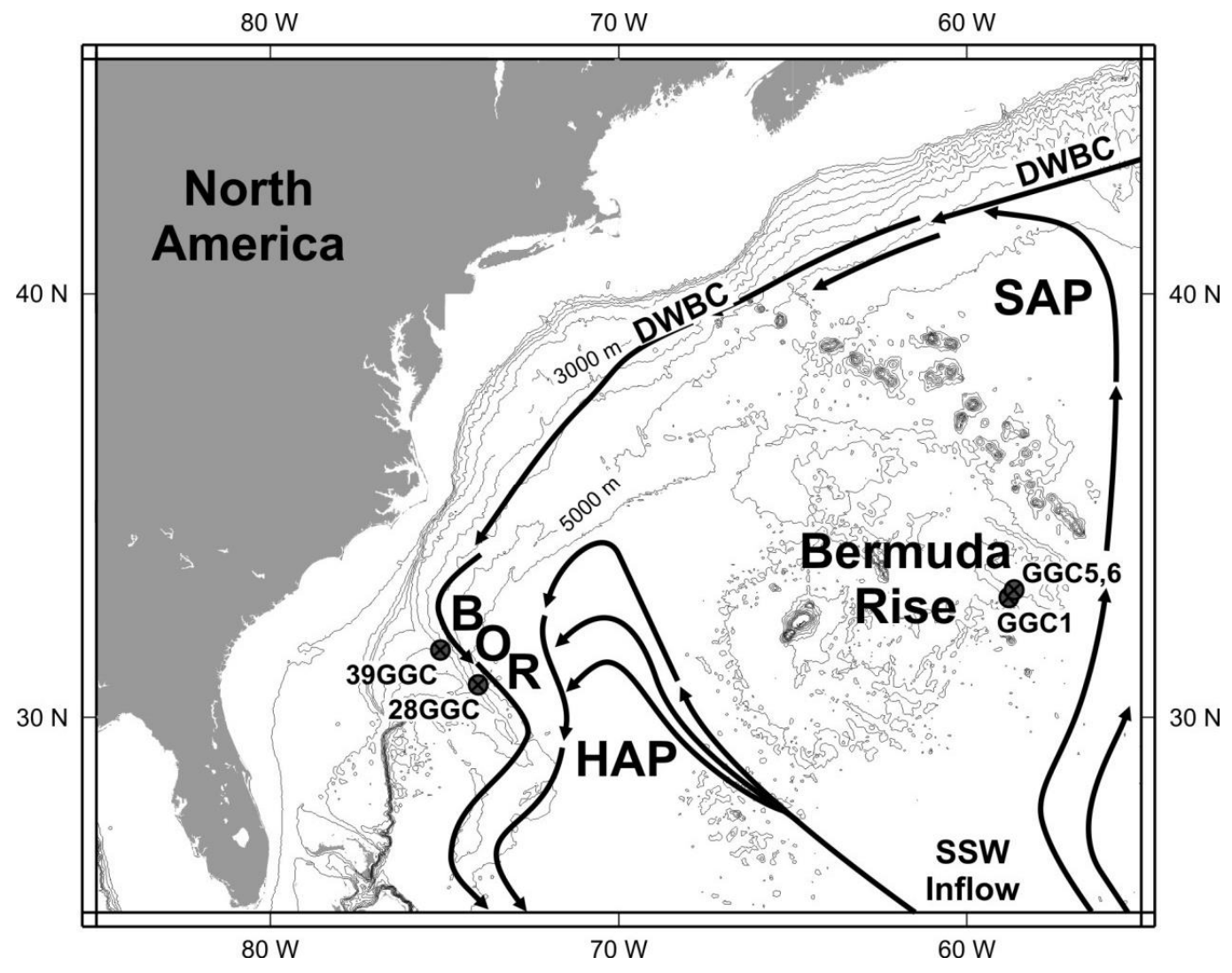


Figure 2.

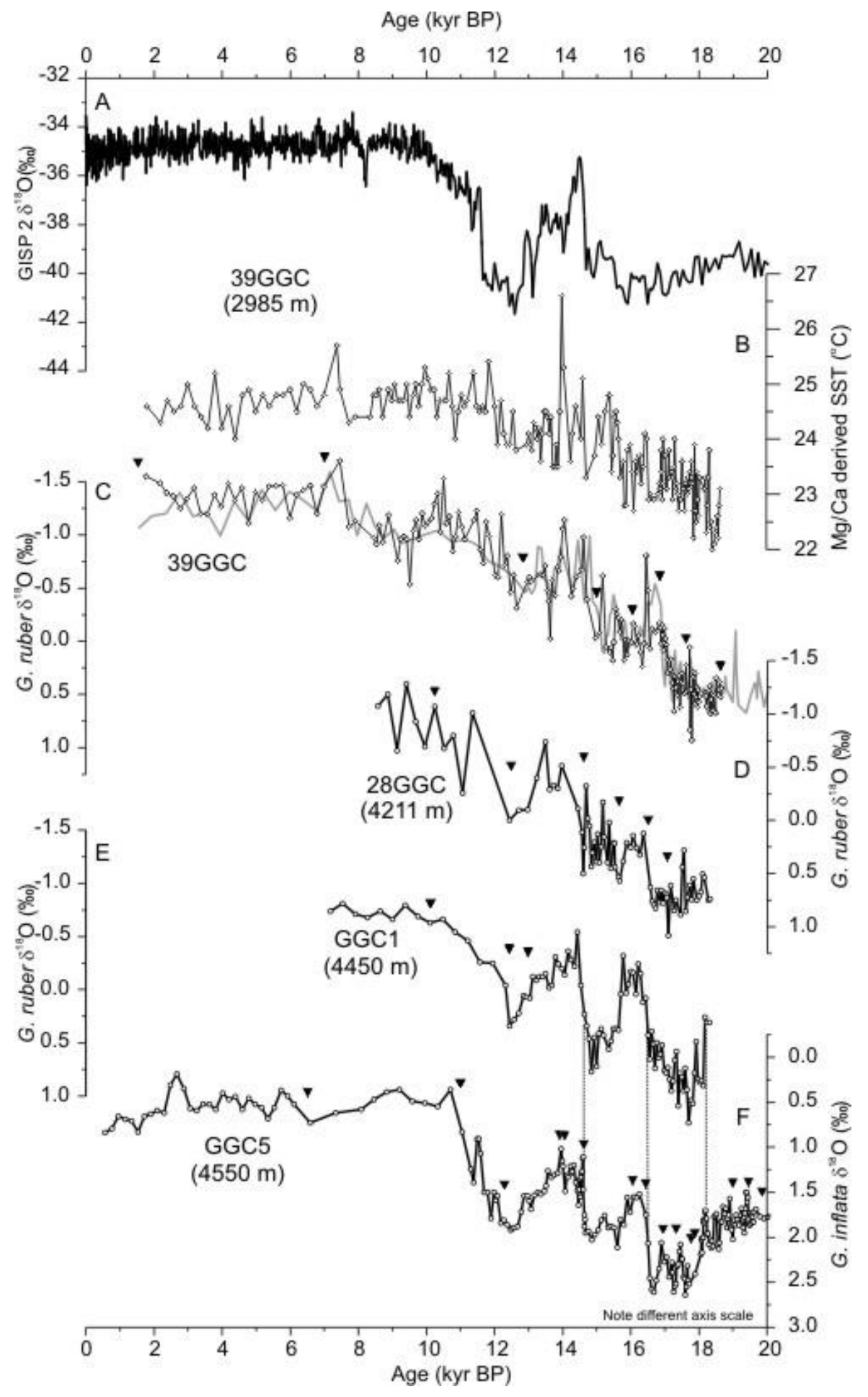


Figure 3.

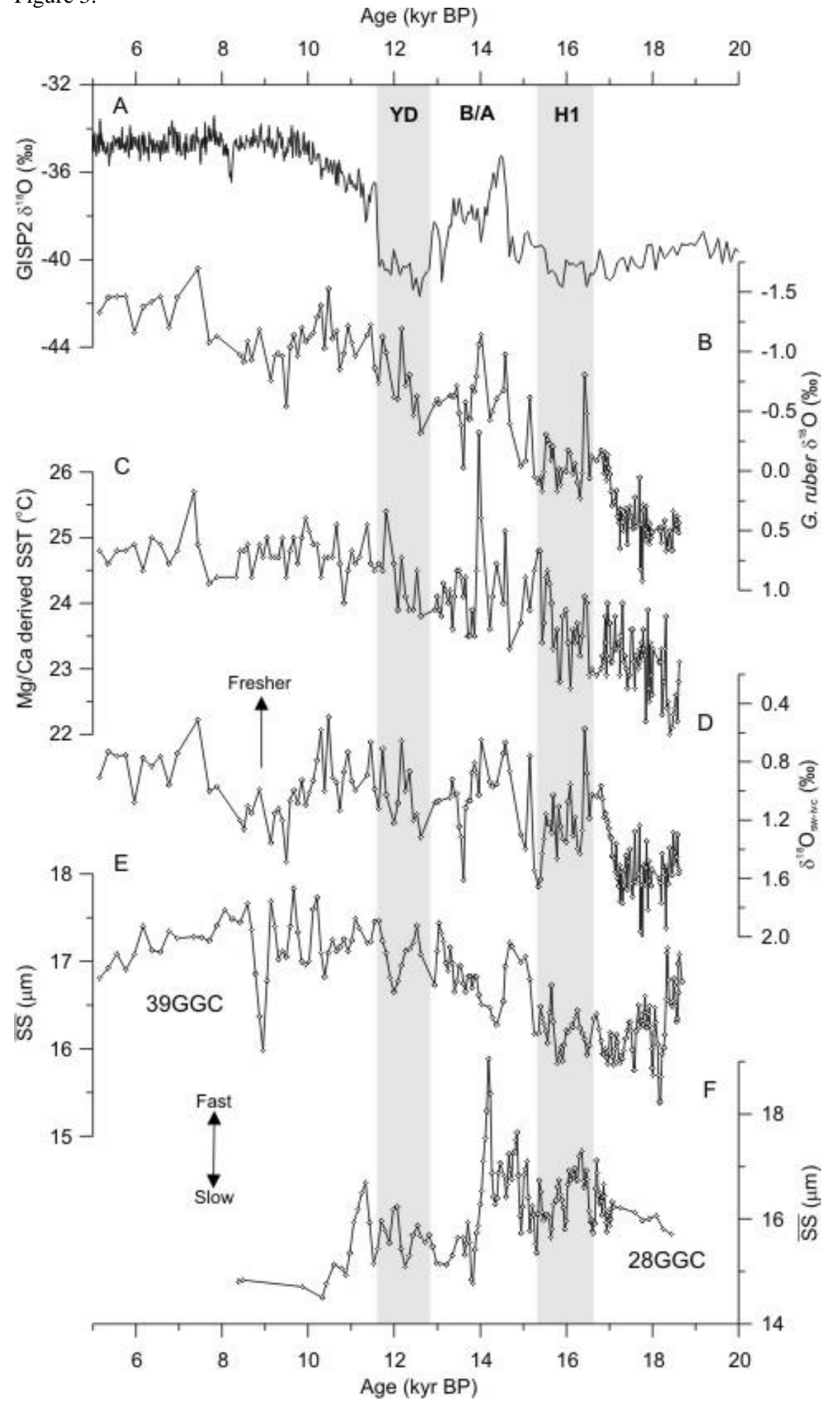


Figure 4.

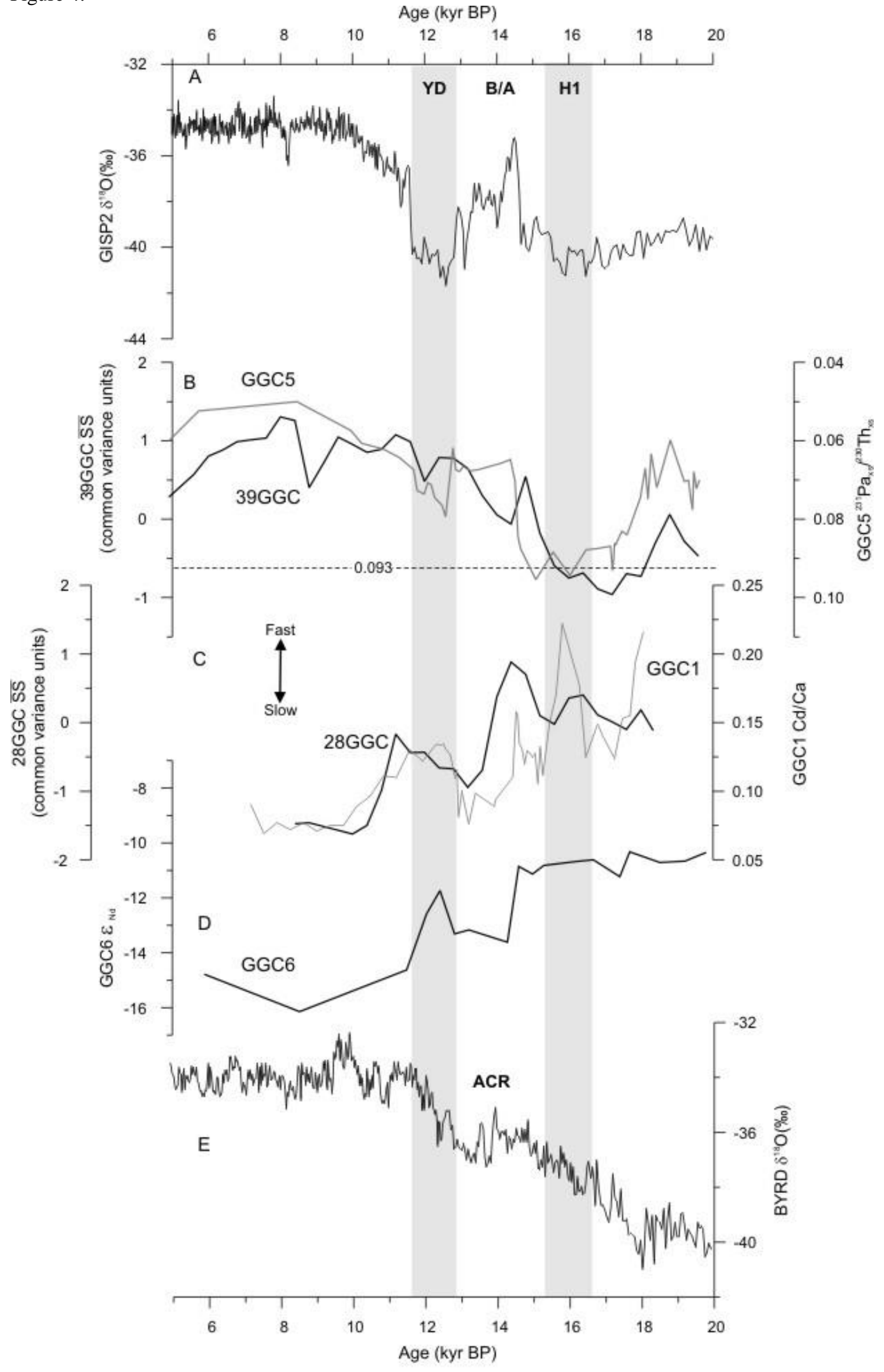

